\title{
THE SIGNIFICANCE OF LIVESTOCK AS A CONTRIBUTOR TO GLOBAL GREENHOUSE GAS EMISSIONS TODAY AND IN THE NEAR FUTURE
}

\author{
Thakshala Seresinhe \\ Emeritus Professor, Department of Animal Science, Faculty of Agriculture, Mapalana, \\ Kamburupitiya, Sri Lanka.
}

\begin{abstract}
In animal agriculture, the greatest contributors to methane emissions are enteric fermentation and manure management. Enteric methane emissions were higher with ruminant animals while manure storage methane was higher with swine and poultry. The main course of agricultural nitrous oxide emissions is from the application of nitrogen fertilizers and animal manures. The most cost-effective way to reduce $\mathrm{CH}_{4}$ production is to improve feed efficiency. In low-intensity systems, $\mathrm{CH}_{4}$ production per unit product can be markedly reduced by improving feed quality and feeding intensity. Inhibition of methanogens, involvement of other $\mathrm{H}_{2}$ alternative sinks e.g. inclusion of dietary fat, can result in a reasonable reduction in $\mathrm{CH}_{4}$ production. Generally, some feed additives such as condensed tannins (CTs), fibrolytic enzymes and other factors e.g. methane inhibitors, vaccines, defaunating agents etc, have the potential to mitigate $\mathrm{CH}_{4}$ production from ruminants. However, there are also some disadvantages, e.g. they are costly and not economical to apply at the farm level, and many have only short-term effects on $\mathrm{CH}_{4}$ production thereby diluting the maintenance costs. The range of global mitigation potential to improve carbon sequestration and other factors are documented. Global and Sri Lankan scenarios on emissions and emission intensities from dairy production and the mitigating options are discussed. It is highlighted that removing animal agriculture is not a good solution to reduce greenhouse gas emissions. It is also suggested that combining productivity increases in crop and livestock sectors appears to be the most efficient way to exploit mitigation and food security co-benefits.
\end{abstract}

Keywords: Dairy cows, Enteric methane, Emission intensity feed efficiency, Mitigating ability, Ruminant

\section{INTRODUCTION}

Livestock production contributes greenhouse gases $(\mathrm{GHG})$ to the atmosphere both directly and indirectly (IPCC 2007). The emissions can be classified based on the source of the emission; 1) Mechanical, and 2) Non-mechanical. The majority of direct $\mathrm{CO}_{2}$ emissions from animal agriculture are usually from fossil use; for example, the use of propane or natural gas in furnaces or incinerators and the use of fuel to operate farm equipment and generators results mostly in $\mathrm{CO}_{2}$ emissions (Dunkley and Dunkley 2013), This type of emission can be described as "mechanical emissions." The use of electricity on animal production farms results in indirect emissions since the emissions do not occur on site. For non-mechanical emissions, methane from enteric fermentation and manure management are the main sources of $\mathrm{CH}_{4}$ emissions from agricultural activities and

Corresponding author: tseresinhe@googlemail.com of all domestic livestock, dairy and beef cattle are the largest emitters of $\mathrm{CH}_{4}$. Enteric fermentation produces methane as a natural part of digestion in ruminant animals. It accounts for 33 percent of the total GHG emissions in agriculture and 71 percent of all agricultural sources of methane. Activities related to the storage and land application of manure releases 12 percent of the total agricultural methane emissions, and represent 25 percent of all agricultural sources of methane. Other significant sources on farms and ranches include rice cultivation and the burning of agricultural residues.

The majority of the $\mathrm{N}_{2} \mathrm{O}$ emission from animal agriculture is from manure management which is the second largest (a far second to cropping practices) $\mathrm{N}_{2} \mathrm{O}$ emitter in the agricultural sector. Application of nitrogenous fertilizers and cropping practices are estimated to 
cause $78 \%$ of total nitrous oxide emissions (IPCC 2006). Indirect emission of $\mathrm{N}_{2} \mathrm{O}$ occurs when nitrogen is lost from the system through volatilization as $\mathrm{NH}_{3}$ and $\mathrm{N}_{2} \mathrm{O}$ (Dunkley and Dunkley 2013 ). Also, indirect emissions can result from nitrogen that is runoff or leached from manure management systems in a form other than $\mathrm{N}_{2} \mathrm{O}$ and is later converted to $\mathrm{N}_{2} \mathrm{O}$ offsite (IPCC 2006). Nearly 53 percent of agricultural GHG emissions are from nitrous oxide. Ninety-two percent of nitrous oxide is from agricultural soil management. Other significant sources include manure management and the burning of agricultural residues.

The degree to which human activities, including animal agriculture production, contributes to climate change is largely unknown. However, efforts are underway to identify all major sources of GHGs to determine strategies aimed at reducing these emissions. While animal agriculture contributes only a small amount (about 3 percent) of all GHG emissions, producers should know the issues and consider alternatives to reduce their overall carbon footprint.

\section{Emissions from enteric Fermentation}

Methane in the rumen is produced by methanogenic bacteria and protozoa. The role of protozoa in methane formation is interesting. It has been established that virtually all of the bacteria attached to protozoa are methanogens (Vogels et al. 1980) and that these bacteria are responsible for between 25 and 37 percent respectively of the total methane produced (Newbold et al. 1995).

By removing the protozoal population through defaunation, the ruminal bacterial population can be modified, volatile fatty acid (VFA) production shifted from acetate and butyrate towards propionate, and methane emissions decreased. However, there is a negative impact on fiber digestion (Demeyer 1991).

Hindgut fermentation differs from rumen fermentation by a substantially lower methane production and the presence of reductive acetogenesis or dissimilatory sulfate reduction. Sulfate reduction and methanogenesis seem to be mutually exclusive, while methanogenesis and reductive acetogenesis may occur simultaneously in the hindgut (Immig 1996).

\section{Factors affecting enteric methane produc- tion}

Johnson and Johnson (1995), suggested that a range of factors such as feed intake, type of carbohydrate fermented, forage processing and lipid addition affect enteric methane emissions. These factors have their effects by two different mechanisms. The first mechanism described is the amount of carbohydrate that is fermented in the reticulo-rumen. The second mechanism is the amount of available hydrogen and the consecutive methane formation through the ratio of VFA produced. The relation between the production of propionic and acetic acids has a relevant impact on methane production. The VFA's regulate the hydrogen supply which controls the production of methane. If carbohydrates would be fermented to acetic acid only, the energy loss from methane formation would be $33 \%$ (Wolin and Miller 1988). If the ratio of acetic and propionic acid was 0.5 , the loss of energy as methane would be $0 \%$.

\section{Methane production from Livestock}

Fig.1 illustrates that the enteric methane emissions are higher with ruminant animals while manure storage methane is higher with swine followed by poultry. On the contrary manure storage, nitrous oxide was highest with poultry followed by swine. Both parameters were low with ruminant animals.

\section{Feed characteristics and methane produc- tion}

There are some feed characteristics which influence $\mathrm{CH}_{4}$ production, as the rumenfermented organic matter has a close relationship with $\mathrm{CH}_{4}$ production. Diets containing highly digestible fiber tend to lead to an increase in digestibility and consequently promote $\mathrm{CH}_{4}$ production. Factors such as forage maturity and its physical form also influence $\mathrm{CH} 4$ production (Moss et al. 2000). For example, $\mathrm{CH}_{4}$ production is lower in animals fed milled and pelleted forages compared with chopped forages (Hironaka et al. 1996). It was reported that a diet with high content of pea/oat silage decreases the amount of enteric 


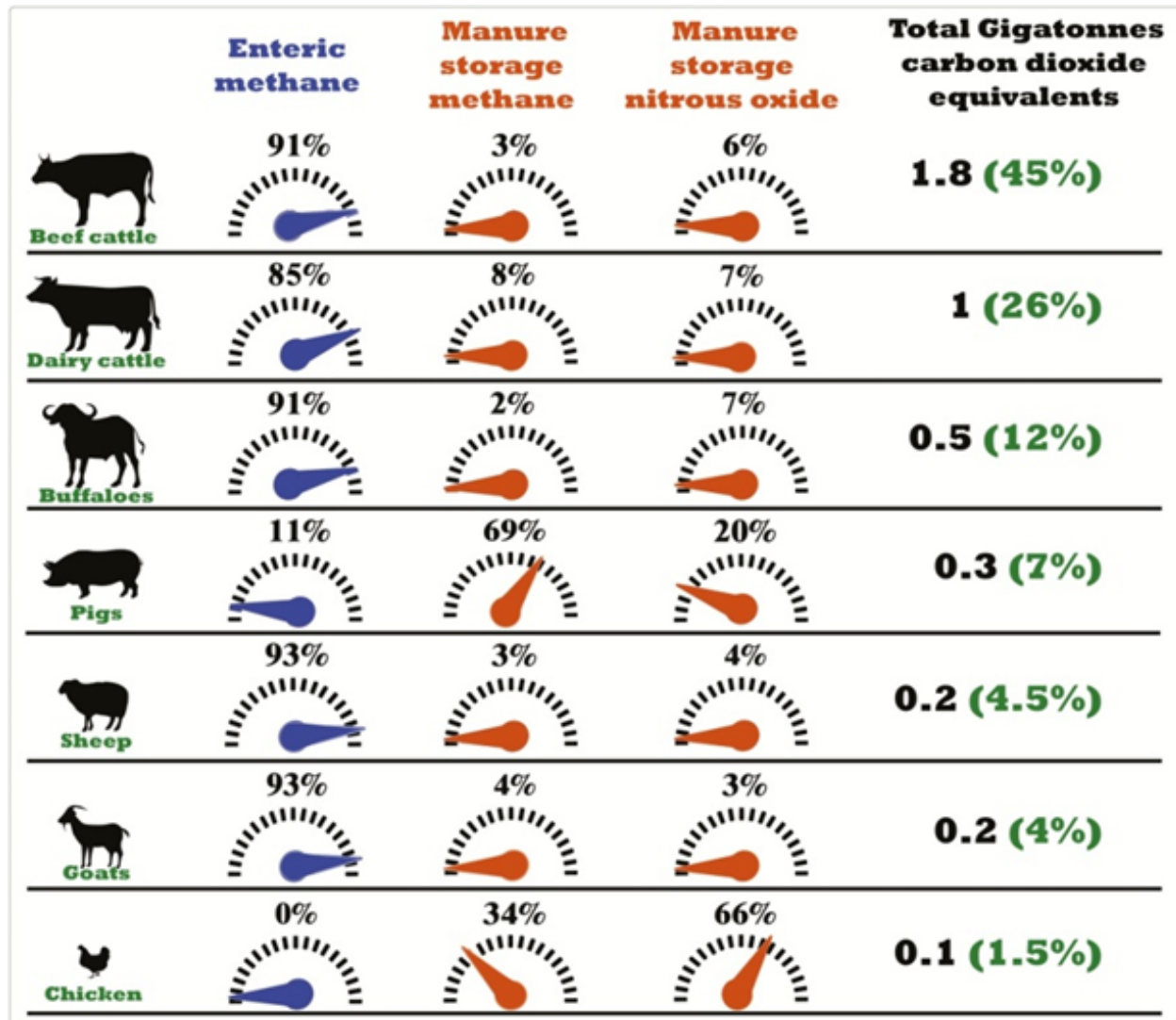

Figure 1: Livestock and climate change: impact of livestock on climate and mitigation strategies. Source: Giampiero Grossi et al.

2019.

methane compared to a diet with grass silage. Diets with pea/oat silage contain as expected, significantly higher amounts of starch than diets with grass silage. It was however not shown that a diet with high content of pea/oat silage generates less methane per $\mathrm{kg}$ of ingested starch than a diet with grass silage (Wirsenius et al. 2011)

\section{Digesta passage rate and ambient tempera- ture}

It has been suggested that a cold environment may influence $\mathrm{CH}_{4}$ production, mainly because the rumen passage rate increases in the cold climate, thereby decreasing $\mathrm{CH}_{4}$ production (McAllister et al. 1996). Lower temperature decreases the ratio of acetate/propionate in sheep, resulting in a shift to propionate production instead of $\mathrm{CH}_{4}$ production (McAllister et al. 1996). It has also been reported by Shibata and Terada, (2010) that in natural tropical environments, the content of components in the cell wall of plants such as acid detergent fiber (ADF) and lignin tends to increase. These increases result in lower digestibility of feed and higher energy losses, causing an increase in $\mathrm{CH}_{4}$ production per unit of product through the decrease in the efficiency of animal production (Shibata and Terada 2010).

\section{Diet composition}

The inclusion of concentrate is suggested to be a solution for mitigation purposes, as it shifts the fermentation towards propionate production. However, Sveinbjörnsson et al., (2006) found that the effect of starch on propionate production was small. McGinn et al., (2006) found the opposite effect, i.e. that increased concentration in the diet increased $\mathrm{CH}_{4}$ production per unit dry matter intake (DMI). The inclusion of concentrate generates a higher amount of fermentable organic matter per unit of feed than with roughage alone, resulting in increased $\mathrm{CH}_{4}$ production. The effect mainly depends on the inclusion level, 
the effect on fiber digestibility and the type of grain used (Hristov et al. 2013). The inclusion of high sugar grasses can increase the efficiency of microbial growth in the rumen, by directing feed $\mathrm{N}$ into microbial protein and diverting $\mathrm{H}_{2}$ to microbial cells rather than $\mathrm{CH}_{4}$ production (Hristov et al. 2013). Stoichiometric fermentation equations published by Bannink et al. (2000) show concordantly that fermentation of sugar results in higher production of butyrate and lower production of propionate than fermentation of starch. On this basis, replacement of sugar by starch in the feed ration is expected to decrease methane production as actually shown by simulation with dynamic, mechanistic models (Mills et al. 2001; Kebreab et al. 2004) in which the fermentation equations of Bannink et al. (2008) were applied.

\section{Dietary fat supplements}

Supplementation of the ruminant diet with fat (oleic, linoleic and linolenic) is an effective method of suppressing $\mathrm{CH}_{4}$ production (Beauchemin et al. 2009; Grainger and Beauchemin 2011). However, supplementation with fat is not always effective, as reported by Johnson et al. (2002). Using high levels of fat to reduce $\mathrm{CH} 4$ production can decrease DMI and productivity (Hristov et al. 2013). In most cases, the diet costs also increase, since feed energy is usually more expensive in fat than in cereal grains. However, according to a metaanalysis of a large data set from production trials, the optimal concentration of concentrate fat is $30-40 \mathrm{~g} / \mathrm{kg}$ diet dry matter (DM) (Huhtanen and Nousiainen 2012). Consequently, small amounts of supplementary fat can both increase productivity and reduce $\mathrm{CH}_{4}$ production. A summary of feeding man-

Table 1: Summary of feeding management approaches to altering rumen fermentation and reducing $\mathrm{CH}_{4}$ emissions per unit of energy corrected milk (ECM) ${ }^{1}$.

\begin{tabular}{llr}
\hline Feeding alteration & $\mathbf{C H}_{\mathbf{4}} \mathbf{E C M}$ & \multicolumn{1}{c}{ Assumption(s) and comments } \\
\hline Increased DMI & Decreased 2 to 6\% for (a) Increased fill; (b) increased rate of sol- \\
each kilogram increase in ids passage; (c) decreased rumen neutral & detergent fiber (NDF) digestibility will be \\
DMI & compensated by increased hindgut NDF \\
& digestibility; (d) decreased rumen starch \\
& digestibility; (e) increased starch digestion \\
& in the small intestine; (f) no difference in \\
& total-tract starch digestion; (g) increased \\
& production \\
\hline
\end{tabular}

Decreased forage particle Neutral
size

(a) Increased passage of forage particles from the rumen; (b) decreased rumen NDF digestibility will be compensated by increased hindgut NDF digestibility

Grain processing
Decreased 1 to $2.5 \%$ with (a) Decreased grain particle passage from a 5\% increase in apparent rumen; (b) increased VFA yield with the total-tract starch digesti- increased proportion of propionate; (c) no bility increase in intake of digestible DM (which may or may not be true)

Rumen $\mathrm{pH}<5.5 \quad$ Decreased 15 to $20 \%$

(a) Decreased rumen NDF digestibility not fully compensated for by hindgut fermentation; (b) assumes 50\% reduction in apparent total-tract NDF digestibility; (c) milk yield reduced 10 to $15 \%$; (d) no change in rumen starch digestibility and no effect on DMI 
Table 1 Continued

\begin{tabular}{|c|c|c|}
\hline Feeding alteration & $\mathrm{CH}_{4} / \mathbf{E C M}$ & Assumption(s) and comments \\
\hline $\begin{array}{l}\text { Increased concentrate feed- } \\
\text { ing }\end{array}$ & $\begin{array}{l}\text { Decreased } 2 \% \text { for every } \\
1 \% \text { increase in ration } \\
\text { NFC; maximum reduc- } \\
\text { tion } \sim 15 \%\end{array}$ & $\begin{array}{l}\text { (a) Effects manifested by less NDF fer- } \\
\text { mented in the total tract, the shift of starch } \\
\text { digestion from the rumen to the small in- } \\
\text { testine, and possibly lower rumen pH; (b) } \\
\text { potential to increase intake; (c) higher } \\
\text { proportions of propionate }\end{array}$ \\
\hline
\end{tabular}

Increased forage quality achieved by better management of harvesting and storage or pasture management

Forage type/strain selection Decreased 0 to $4 \%$ and genetics (eg. brown midrib corn)
Decreased up to $5 \%$ with (a) Increased yield of VFA (energy) is a 5 percentage unit in- greater than increases in $\mathrm{CH} 4$; (b) increase in apparent total- creased milk yield tract NDF digestibility

\begin{tabular}{lll}
\hline Lipid feeding & $\begin{array}{l}\text { Decreased 5\% per unit of } \\
\text { ether extract in ration }\end{array}$ & $\begin{array}{l}\text { Potential for (a) decreased DMI, (b) de- } \\
\text { creased NDF digestibility, (c) decreased } \\
\text { lactation performance, and (d) decreased } \\
\text { milk components }\end{array}$ \\
\hline
\end{tabular}

\begin{abstract}
${ }^{1}$ Many of the biological effects are interrelated and interdependent and, accordingly, the changes in enteric $\mathrm{CH} 4$ emissions per unit of ECM (CH4/ECM) are not likely to be additive. Expected decreases in CH4/ECM range from 0 to $15 \%$. These changes are modest because the range of alterations was restricted to what might reasonably be implemented or occur in commercial dairy production without compromising milk yield significantly (except as noted for rumen $\mathrm{pH}$ ) compared with previously published reviews where the manipulations ranged from all-forage to allconcentrate diets for nonlactating and lactating animals. Manipulations that alter carbohydrate digestibility and thus energy availability will affect milk yield as well as $\mathrm{CH} 4$ emissions.

Source: Knapp et al. (2014)
\end{abstract}

agement approaches to altering rumen fermentation and reducing $\mathrm{CH}_{4}$ emissions per unit of energy corrected milk (ECM) are shown in the Table 1.

\section{Condensed Tannins (CTs)}

The effect of CTs on rumen fermentation show that CTs exhibit strong antibacterial activity on fibrolytic species often resulting in reduced digestibility of NDF and ADF. Responses of methanogens to CT have been noted to be type and dose-dependent. Jayanegara et al. (2009) reported an inverse relationship between dietary tannin concentration and $\mathrm{CH}_{4}$ production per unit of digestible organic matter $(\mathrm{OM})$ in rumen fermentation. Tavendale et al. (2005) reported both bacteriostatic and bactericidal properties of Lotus pedunculatus on the common rumen methanogen Methanobrevibacter ruminantium in vitro. Waghorn et al. (2002) evaluated the potential of Lotus pedunculatus and reported a $16 \%$ reduction in methane production (in $\mathrm{g} \mathrm{CH}_{4} \mathrm{~kg}-1$ dry matter intake) in lambs due to the presence of CTs in the forage. Similarly, Carulla et al. (2005) observed a $13 \%$ reduction in $\mathrm{CH}_{4}$ emissions when Acacia mearnsii CT extract was administered at $25 \mathrm{~g} / \mathrm{kg}$ feed DM to sheep. Condensed tannin forage and condensed tannin extract used in literature have however shown wide variation in their anti-methanogenic effect, which according to Mané et al. (2007), is related to their average molecular weight and the degree of polymerization of the CTs. The chemical structure and molecular weight of CTs have been observed to play a significant role in their biological activity (Naumann et al. 2014) and 26 condensed tannin-protein interactions (Soares et al. 2007).

\section{Use of fibrolytic enzymes}

Sujani and Seresinhe (2015), reviewed that fibrolytic enzyme application showed inconsistent but positive responses on feed intake, 
nutrient digestibility, growth performance, production parameters and manure nutrient excretion etc. in the studies done with ruminants like cattle both dairy and beef, goat, sheep and less with buffalo. Mohamed (2013), found that supplementation of early lactating dairy cow diet with fibrolytic enzymes (Enzyme was added to the total mixed ration at the time of feeding), did not cause any significant changes in dry matter intake but milk yield was improved significantly. Soltan et al. (2013) reported that the use of exogenous enzymes, particularly cellulases, increases $\mathrm{CH}_{4}$ production, indicating that there is a forage-enzyme interaction. The above results are consistent with the findings of Gemeda and Hassen (2015) who observed an increasing volume of methane gas with increasing levels of enzyme application for the feeds treated with enzymes, compared to the control samples. Likewise, Arriola et al. (2011) observed that, in cows fed high concentrate diets, enzyme supplementation decreased the acetate: propionate ratio in rumen fluid, and hence a reduction in methane production (calculated from VFA profiles, using a fermentation balanced approach). The results of Seresinhe et al. (2017) concur with those of Giraldo et al. (2008) who found that methane production was not influenced by fibrolytic enzyme supplementation. In an in-vitro study conducted by Togtokhbayar et al. (2015)

Table 2: Use of methane inhibitors in reducing enteric methane production.

\begin{tabular}{|c|c|c|c|}
\hline Name of inhibitor & Action & Adverse / desirable effects & Source \\
\hline $\begin{array}{l}\text { Chloroform, amichloral } \\
\text { and 2-25 } \\
\text { ethanesulphonic } r \text { acid } \\
\text { (BES) }\end{array}$ & Suppress methanogenesis & $\begin{array}{l}\text { Liver damage and even } \\
\text { death }\end{array}$ & $\begin{array}{l}\text { Dong et al. } \\
1999\end{array}$ \\
\hline $\begin{array}{l}2-25 \text { bromoethanesul- } \\
\text { phonic acid (BES) }\end{array}$ & $\begin{array}{l}\text { Effect of } \mathrm{BES} \text { is momen- } \\
\text { tary and } \mathrm{CH}_{4} \text { production } \\
\text { rapidly returns to its origi- } \\
\text { nal level of emission within } \\
\text { some days }\end{array}$ & & $\begin{array}{l}\text { McAllister } \\
\text { and Newbold } \\
2008\end{array}$ \\
\hline Fungi & $\begin{array}{l}\text { Reduction in total gas pro- } \\
\text { duction after fermenting } \\
\text { palm kernel cake }\end{array}$ & $\begin{array}{l}\text { The reduction could be due } \\
\text { to the production of some } \\
\text { special compounds such as } \\
\text { statins during the fermenta- } \\
\text { tion, thereby inhibiting the } \\
\text { emission of gases }\end{array}$ & $\begin{array}{l}\text { Ramin et al. } \\
2010\end{array}$ \\
\hline
\end{tabular}

HMG-CoA (mevastatin) Mostly cellulolytic, inhibit- Without causing any growth Wolin and in vitro to a co-cuture ed the growth of Methano- inhibition on other bacterial Miller, 2006 comprising $\quad \mathrm{CH}_{4}$ - brevibacter. species.

producing bacteria and

other eubacterial spe-

cies.

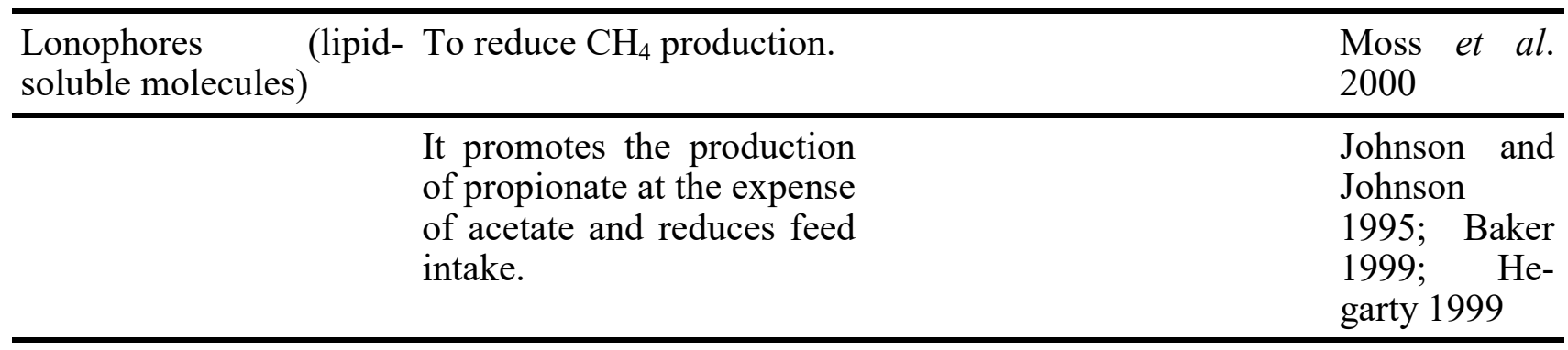


Table 2 Continued

\begin{tabular}{|c|c|c|c|}
\hline Name of inhibitor & Action & Adverse / desirable effects & Source \\
\hline Monensin & $\begin{array}{l}\text { Gram-negative bacteria are } \\
\text { resistant. }\end{array}$ & $\begin{array}{l}\mathrm{CH}_{4} \text {-producing Gramposi- } \\
\text { tive bacteria are not resistant } \\
\text { to ionosphere antibiotics. }\end{array}$ & $\begin{array}{l}\text { Wolin and } \\
\text { Miller } 2006\end{array}$ \\
\hline Monensin & $\begin{array}{l}\text { Causes high intracellular } \\
\text { NADH/NAD+, which reox- } \\
\text { idises NADH while limiting } \\
\text { the } \mathrm{H}_{2} \text {-yielding acetate } \\
\text { pathway. }\end{array}$ & $\begin{array}{l}\text { Lonophoric antibodies (eg. } \\
\text { monensin and related com- } \\
\text { pounds) are prohibited with- } \\
\text { in the European Union coun- } \\
\text { tries. }\end{array}$ & Hegarty 1999 \\
\hline $\begin{array}{lr}\text { Commercial } & \text { allicin } \\
\text { products } & \text { originating } \\
\text { from garlic } & \end{array}$ & $\begin{array}{l}\text { Effective in inhibiting } \mathrm{CH}_{4} \\
\text { production at a dose of } 20 \mathrm{~g} / \\
\mathrm{mL} \text { without any adverse } \\
\text { effect on daily VFA pro- } \\
\text { duction. }\end{array}$ & $\begin{array}{l}\text { The inhibitory effect was } \\
\text { mainly a direct effect on } \\
\text { methanogen DNA. }\end{array}$ & $\begin{array}{l}\text { McAllister } \\
\text { and Newbold } \\
2008\end{array}$ \\
\hline Hops acid & $\begin{array}{l}\text { Increasing the concentra- } \\
\text { tion of hops acid from } 50 \text { to } \\
400 \mathrm{~g} / \mathrm{mL} \text { in an in vitro gas } \\
\text { production system, } \mathrm{CH}_{4} \\
\text { production quadratically } \\
\text { decreased per unit DM di- } \\
\text { gested. }\end{array}$ & & $\begin{array}{l}\text { Narvaez et al. } \\
2011\end{array}$ \\
\hline $\begin{array}{l}\text { Egg Albumin (EA), chi- } \\
\text { tosan }(\mathrm{CH}) \text { and polyeth- } \\
\text { ylene glycol (PEG). }\end{array}$ & $\begin{array}{l}\text { Supplementing EA, } \mathrm{CH} \text { and } \\
\text { PEG are beneficial in terms } \\
\text { of In Vitro Gas Production, } \\
\text { Short Chain Fatty Acids } \\
\text { and Ammonia nitrogen } \\
\left(\mathrm{NH}_{3}-\mathrm{N}\right) \text { production but no } \\
\text { significant effect on me- } \\
\text { thane production. }\end{array}$ & & $\begin{array}{l}\text { Sujani et al. } \\
2017\end{array}$ \\
\hline $\begin{array}{l}\text { Polyethylene } \\
\text { (PEG) }\end{array}$ & $\begin{array}{l}\text { Good relationship between } \\
\text { PEG binding and the im- } \\
\text { provement of In Vitro Dry } \\
\text { Matter Digestibility of C. } \\
\text { calothyrsus as a result of } \\
\text { lower invitro gas produc- } \\
\text { tion }\end{array}$ & & $\begin{array}{l}\text { Seresinhe and } \\
\text { Iben, } 2003\end{array}$ \\
\hline
\end{tabular}

where they have used Xylanase supplemented to wheat straw in goat rumen fluid, they observed increased $\mathrm{CH}_{4}$ production, linearly at $24 \mathrm{~h}$ of incubation. Table 2 summarized the use of methane inhibitors in reducing enteric methane production.

\section{Defaunation}

Protozoa are microorganisms living in the rumen that contribute up to $50 \%$ of fibrolytic activity within the rumen (Coleman, 1986). Defaunation is an effective mitigation strategy, i.e. elimination of protozoa from the rumen results in a decrease in $\mathrm{CH}_{4}$ production (Moss et al. 2000; McAllister and Newbold 2008). Defaunation can be done by lowering the $\mathrm{pH}$ in the rumen (feeding grain) or giving oils such as highly unsaturated $\mathrm{C}_{18}$ fatty acids (linseed oil) to the animal (Hegarty 1999). Defaunation is a process that disrupts the cross- 
feeding between ruminal protozoa and Archaea in the rumen. Defaunation increases the proportion of propionate in the rumen improves the efficiency of microbial cell synthesis and decreases diet digestibility (Eugène et al. 2008), all of which can contribute to reduced $\mathrm{CH}_{4}$ production.

\section{Vaccines and other factors}

Vaccination is a novel strategy to reduce $\mathrm{CH}_{4}$ production in ruminants. It is based on a continuous supply of antibodies to archaea through the saliva in the animal. However, attempts to use vaccines in vivo against methanogens have not been successful (Wright et al. 2004). One reason could be the growth of other methanogenic strains in the rumen to replace those methanogens against which the antibodies are generated (McAllister and Newbold 2008). However, the vaccination strategy to reduce $\mathrm{CH}_{4}$ production is an attractive method, as it can be applied to all types of ruminants. Biological strategies to control methanogens is one approach for influencing $\mathrm{CH}_{4}$ production. Archaeal viruses and bacteriocins, eg. nisin produced by Lactococcus lactis, are safe natural feed additives that can be used to control rumen methanogens. Archaeal viruses (eg. bacteriocins) are biological treatments that raise the $\mathrm{H} 2$ pressure sufficiently in the rumen to initiate acetogenesis (Klieve and Hegarty 1999).

Table 3: Description of livestock waste deposition and storage pathways. Source: Dunkley and Dunkley (2013)

\begin{tabular}{|c|c|c|c|}
\hline \multirow[b]{2}{*}{$\begin{array}{l}\text { Manure Management } \\
\text { System }\end{array}$} & \multirow[b]{2}{*}{ Description } & \multicolumn{2}{|c|}{ Relative Emissions } \\
\hline & & $\mathrm{CH}_{4}$ & $\mathbf{N}_{2} \mathrm{O}$ \\
\hline $\begin{array}{l}\text { Pasture/range/paddock } \\
\text { Ex. beef cattle }\end{array}$ & $\begin{array}{l}\text { Manure and urine from pasture and grazing animals is } \\
\text { deposited directly onto soil. }\end{array}$ & Low & High \\
\hline Daily Spread & $\begin{array}{l}\text { Manure and urine are collected and spread on fields } \\
\text { (little or no storage prior to application). }\end{array}$ & Low & Minimal \\
\hline $\begin{array}{l}\text { Solid storage } \\
\text { Ex. poultry }\end{array}$ & $\begin{array}{l}\text { Manure and urine with or without litter are collected and } \\
\text { stored long term in bulk }\end{array}$ & Low & High \\
\hline $\begin{array}{l}\text { Dry lot } \\
\text { Ex. Beef cattle }\end{array}$ & $\begin{array}{l}\text { Manure and urine are deposited directly on unpaved } \\
\text { feedlots where it is allowed to dry. It is periodically re- } \\
\text { moved. }\end{array}$ & Low & High \\
\hline $\begin{array}{l}\text { Liquid/slurry } \\
\text { Ex. Swine/dairy cattle }\end{array}$ & $\begin{array}{l}\text { Manure and urine are collected and transported in liquid } \\
\text { form to tanks for storage. The liquid/ slurry may be } \\
\text { stored for long periods. }\end{array}$ & $\begin{array}{l}\text { Moderate to } \\
\text { high }\end{array}$ & Low \\
\hline $\begin{array}{l}\text { Anaerobic Lagoon } \\
\text { Ex. Swine/dairy cattle }\end{array}$ & $\begin{array}{l}\text { Manure and slurry are collected using a flush system } \\
\text { and transported to lagoons for storage. It remains in la- } \\
\text { goons for 30-200 days. }\end{array}$ & Variable & Low \\
\hline $\begin{array}{l}\text { Pit Storage } \\
\text { Ex. Swine/poultry layers }\end{array}$ & $\begin{array}{l}\text { Combined storage of manure and urine in pits below } \\
\text { livestock confinements. }\end{array}$ & $\begin{array}{l}\text { Moderate to } \\
\text { high }\end{array}$ & Low \\
\hline $\begin{array}{l}\text { Poultry with litter } \\
\text { Ex. Broiler/pullet/ } \\
\text { breeders }\end{array}$ & $\begin{array}{l}\text { Enclosed poultry houses utilize bedding material (ex. } \\
\text { Wood shavings, peanut hull, rice hulls etc.). The bed- } \\
\text { ding absorbs moisture and dilutes manure. Litter is } \\
\text { cleaned out typically once per year. }\end{array}$ & Low & High \\
\hline $\begin{array}{l}\text { Poultry without litter } \\
\text { Ex. Poultry layers/ } \\
\text { broiler breeders }\end{array}$ & $\begin{array}{l}\text { In high-rise cages or scrape-out/belt systems, manure is } \\
\text { excreted onto the floor below with no bedding to absorb } \\
\text { moisture. The ventilation system dries the manure as it } \\
\text { is stored. }\end{array}$ & & High \\
\hline
\end{tabular}




\section{Emissions based on manure management systems.}

According to Dunkley and Dunkley (2013), (Table 3) the type of manure management system that is used in livestock production can affect the amount of emissions and the type of gases that are emitted. Manure management systems practiced in different farms are; pit storage, poultry with/without litter (that is, poultry raised on a bedding material or poultry raised in cages), dry-lot, anaerobic lagoon, pasture, etc.

\section{The role of dung beetles in reducing GHG emissions from cattle farming}

A study was done in Finland, (Slade et al. 2016) assessed GHG emissions at three scales: the dung pat, pasture ecosystem, and whole lifecycle of milk or beef production. At the first two levels, dung beetles reduced GHG emissions by up to $7 \%$ and $12 \%$ respectively, mainly through large reductions in methane $\left(\mathrm{CH}_{4}\right)$ emissions. However, at the lifecycle level, dung beetles accounted for only a $0.05-0.13 \%$ reduction of overall GHG emissions. This mismatch derives from the fact that in intensive production systems, only a limited fraction of all cow pats end up on pastures, offering limited scope for dung beetle mitigation of GHG fluxes. In contrast, they suggested that the effects of dung beetles may be accentuated in tropical countries, where more manure is left on pastures, and dung beetles remove and aerate dung faster. These considerations give a new perspective on previous results and suggest that studies of biotic effects on GHG emissions from dung pats on a global scale are a priority for current research (Slade et al. 2016)

\section{The global scenario on GHG emissions and mitigation}

Herrero et al. (2016) emphasized that the livestock sector supports about 1.3 billion producers and retailers, and contributes 40$50 \%$ of agricultural GDP. They estimated that between 1995 and 2005, the livestock sector was responsible for GHG emissions of 5.6-7.5 $\mathrm{GtCO}_{2} \mathrm{e} \mathrm{yr}^{-1}$. Livestock accounts for up to half of the technical mitigation potential of the agriculture, forestry and land-use sectors, through management options that sus- tainably intensify livestock production, promote carbon sequestration in rangelands and reduce emissions from manure, and reductions the demand for livestock products. The economic potential of these management alternatives is less than $10 \%$ of what is technically possible because of adoption constraints, costs and numerous trade-offs.

O'Mara (2011) reported that as assessed by IPCC, Animal agriculture is responsible for 8$10.8 \%$ of global GHG emissions. However, on the basis of lifecycle analysis, the contribution of livestock is up to $18 \%$ of global emissions. Asia is the source of the most enteric $\mathrm{CH}_{4}$ emissions with Latin America, Africa, Western Europe and North America being significant sources. These emissions are dominated by emissions from cattle. When GHG emissions are related to food production, the four most efficient regions are Eastern and Western Europe, North America, and the non-EU former Soviet Union which produced 46.3\% of ruminant meat and milk energy and only $25.5 \%$ of enteric $\mathrm{CH} 4$ emissions in 2005 . In comparison, the three least efficient producers (Asia, Africa, Latin America) produced an equivalent amount $(47.1 \%)$ of ruminant meat and milk energy and almost $69 \%$ of enteric $\mathrm{CH}_{4}$ emissions in 2005. Livestock related emissions will increase as world population and food demand increases; enteric $\mathrm{CH}_{4}$ emissions were projected to grow by over $30 \%$ from 2000 to 2020 . There are mitigations available now, but it is imperative to develop new mitigations and ways to implement existing technologies more cost-effectively.

\section{GHG emissions from the EU livestock sec- tor}

According to Lesschen et al. (2011), there are increasing concerns about the ecological footprint of global animal production. They reported regional variations in dairy, beef, pork, poultry and egg production, and related GHG emissions in the 27 Member States of the European Union (EU-27), based on 2003-2005 data. Analyses were made with the MITERRA -Europe model which calculates annual nutrient flows and GHG emissions from agriculture in the EU-27. The dairy sector had the highest GHG emission in the EU-27, with an- 
nual emission of $195 \mathrm{Tg} \mathrm{CO}_{2}$-eq, followed by the beef sector with $192 \mathrm{Tg} \mathrm{CO}_{2}$-eq. Enteric fermentation was the main source of GHG emissions in the European livestock sector $(36 \%)$ followed by $\mathrm{N}_{2} \mathrm{O}$ soil emissions $(28 \%)$. On a per $\mathrm{kg}$ product basis, beef had by far the highest GHG emission with $22.6 \mathrm{~kg} \mathrm{CO}$-eq/ $\mathrm{kg}$, milk had an emission of $1.3 \mathrm{~kg} \mathrm{CO}$-eq/ $\mathrm{kg}$, pork $3.5 \mathrm{~kg} \mathrm{CO}-\mathrm{eq} / \mathrm{kg}$, poultry $1.6 \mathrm{~kg}$ $\mathrm{CO}_{2}$-eq/kg, and eggs $1.7 \mathrm{~kg} \mathrm{CO}{ }_{2}$-eq $/ \mathrm{kg}$. However large variations in GHG emissions per unit product exist among EU countries, which are due to differences in animal production systems, feed types and nutrient use efficiencies. These results provide insight into differences in GHG sources and emissions among animal production sectors for the various regions of Europe.

Likewise, Weiss and Leip (2011) presented detailed product-based net emissions of main livestock products (meat, milk and eggs) at the national level for the whole EU-27 according to a cradle-to-gate life-cycle assessment, including emissions from land use and land-use change (LULUC). Total GHG fluxes of European livestock production amounts to 623-852 $\mathrm{Mt} \mathrm{CO}_{2}$-eq; $182-238 \mathrm{Mt} \mathrm{CO}_{2}$-eq $(28-29 \%)$ is from beef production, $184-240$ $\mathrm{Mt} \mathrm{CO}_{2}$-eq (28-30\%) from cow milk production and 153-226 $\mathrm{Mt} \mathrm{CO}_{2}$-eq (25-27\%) from pork production. According to IPCC classifications, $38-52 \%$ of total net emissions are created in the agricultural sector, $17-24 \%$ in the energy and industrial sectors. $12-16 \% \mathrm{Mt}$ $\mathrm{CO}_{2}$-eq are related to land use $\left(\mathrm{CO}_{2}\right.$ fluxes from the cultivation of organic soils and reduced carbon sequestration compared to natural grassland) and 9-33\% to land-use change, mainly due to feed imports. The results suggest that for effective reduction of GHG emissions from livestock production, fluxes occurring outside the agricultural sector need to be taken into account. Reduction targets should address both the production side as defined by IPCC sectors and the consumption side. An LCA assessment as presented here could be a basis for such efforts.

Bustamante et al. (2012) in a study estimated, for the first time, the GHG emissions associated with cattle raising in Brazil, focusing on three principal sources: 1) portion of deforestation resulting in pasture establishment and subsequent burning of felled vegetation; 2) pasture burning; and 3) bovine enteric fermentation. Deforestation for pasture establishment was only considered for the Amazon and Cerrado. Emissions from pasture burning and enteric fermentation were accounted for the entire country. The consolidated emissions estimate lies between approximately $813 \mathrm{Mt}$ $\mathrm{CO}_{2}$ eq in 2008 (smallest value) and approximately 1,090 $\mathrm{Mt} \mathrm{CO}_{2}$ eq in 2003 (greatest value). The total emissions associated with Amazon cattle ranching ranged from 499 to 775 Mt $\mathrm{CO}_{2}$ eq, that of the Cerrado from 229 to $231 \mathrm{Mt} \mathrm{CO}_{2} \mathrm{eq}$, and that of the rest of the country between 84 and $87 \mathrm{Mt} \mathrm{CO}_{2}$ eq. The full set of emissions originating from cattle raising is responsible for approximately half of all Brazilian emissions (estimated to be approximately $1,055 \mathrm{Mt} \mathrm{CO}_{2} \mathrm{eq}$ in 2005), even without considering cattle related sources not explicitly estimated in this study, such as energy use for transport and refrigeration along the beef and derivatives supply chain. The potential for reduction of GHG emissions offered by the Brazilian cattle industry is very high and might constitute Brazil's most important opportunity for emissions mitigation. The study offers a series of policy recommendations for mitigation that can be implemented by public and private administrators at a low cost relative to other GHG reduction options.

\section{Mitigation of GHG emissions at the global level}

In the Fig 2, red represents the range for each practice, where available. The range of mitigation potentials for carbon sequestration due to improved grazing management is defined by Smith et al. (2008) and Clough et al. (2009). The mitigation potentials for $10 \%$ improved digestibility in all ruminants in the developing world are shown, obtained by upscaling values from Thornton and Herrero (2010). Direct application of this option to developed country situations was assumed to be too small to be considered. Full adoption of the practice across all ruminants was assumed to obtain the technical mitigation potential for this practice, hence no range is pre- 


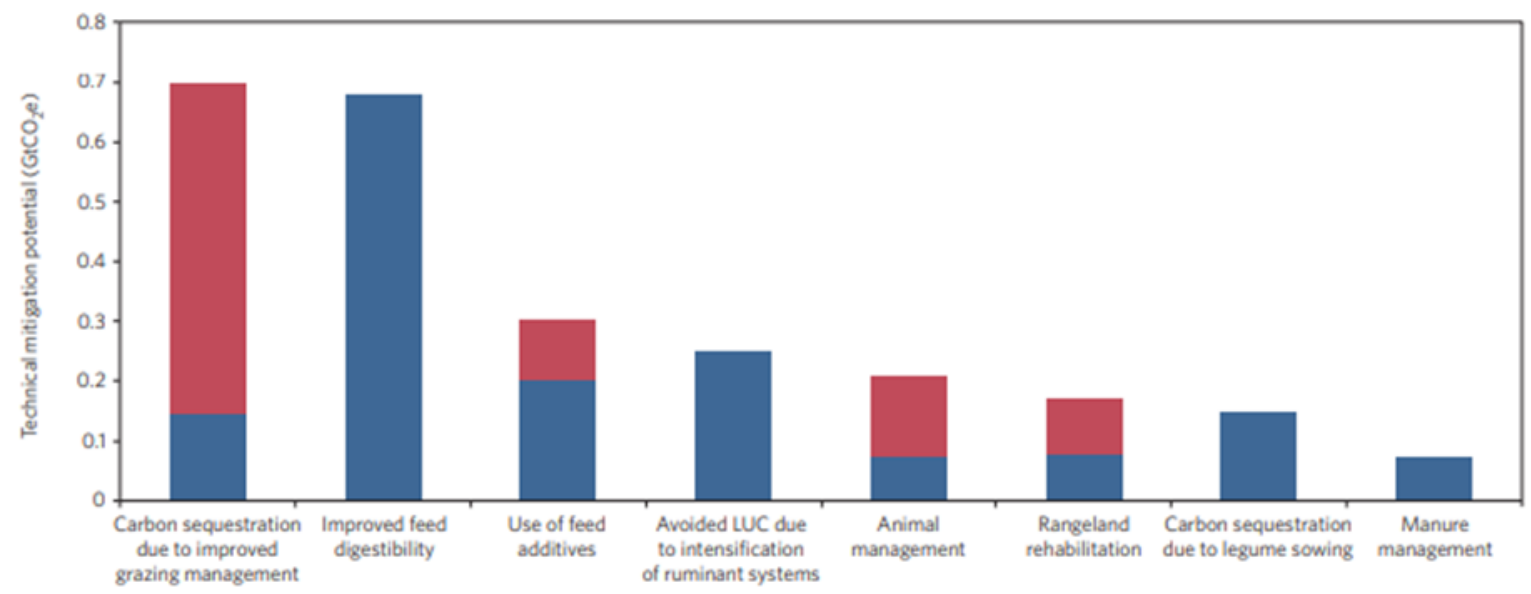

Figure 2: Technical mitigation potentials of supply-side options for reducing emissions from the livestock sector. Source: Herrero et al. 2016.

sented. The mitigation potentials for use of feed additives are from Hristov et al. (2013) and include inhibitors, ionophores, electron receptors, enzymes, plant bioactive compounds, lipids and manipulation of rumen microflora. These potentials are applied to breeding herds of cattle globally with effects on $\mathrm{ECH}_{4}$ as described in Hristov et al. (2013). The mitigation potentials of avoided land-use change from transitions from grazing to mixed crop-livestock systems are from Havlík et al. (2014). The mitigation potentials for animal management practices such as improved health and reduced mortality are from Hristov et al. (2013). and the effects applied as for feed additives. Rangeland rehabilitation mitigation potentials are from Henderson et al. (2015). Manure management mitigation potentials are from Smith et al. (2008).

\section{Sri Lankan Scenario on GHG emission and} mitigation options.

The report published by the Food \& Agriculture Organization \& New Zealand Agricultur-

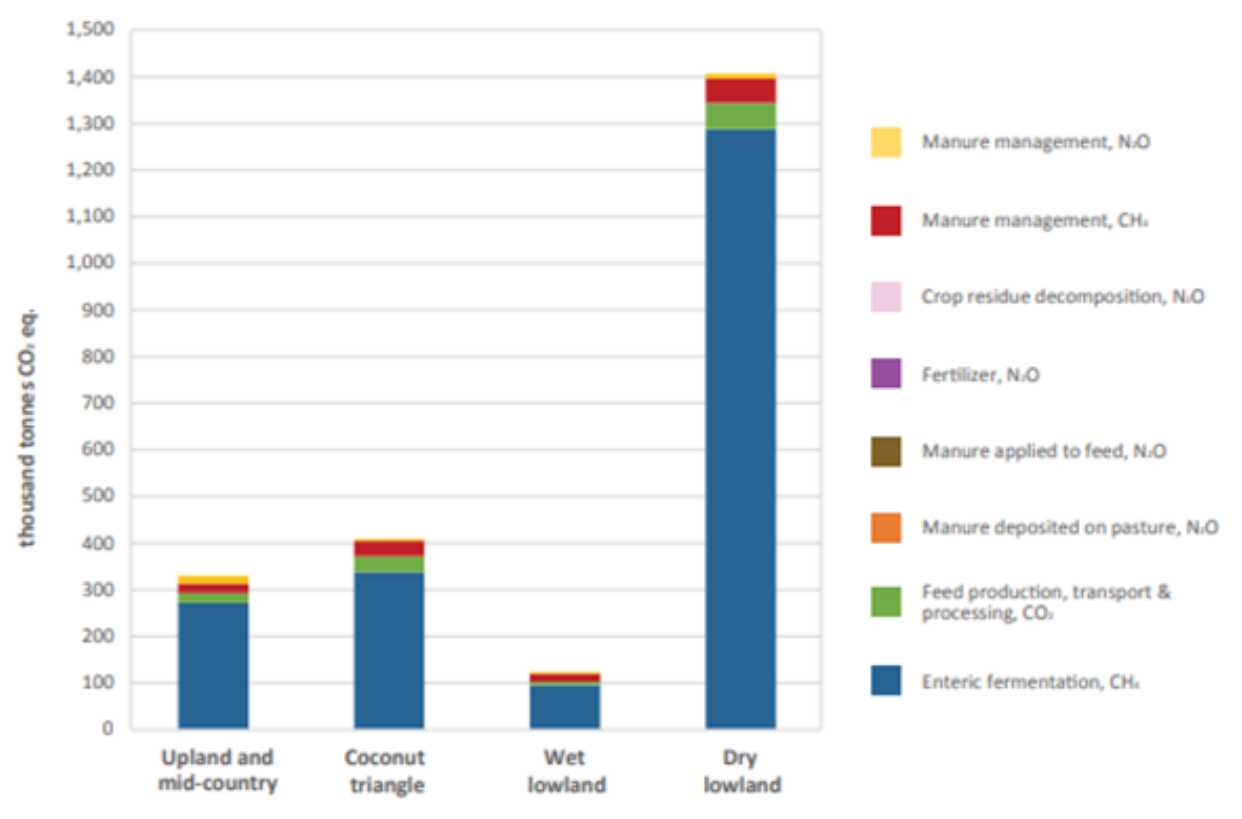

Figure 3: Emission intensity per kg FPCM, by production system in Sri Lanka ( FAO \& NZAGGRC 2017). 
al Greenhouse Gas Research Center (FAO and NZAGGRC) in 2017, the dairy cattle sector produces about 0.32 million tons of milk; of this 43 percent of the milk is produced by the intensive systems in the Upland and Mid-country production zones, while 31 percent, 18 percent and 8 percent are produced in the Dry Lowland, Coconut Triangle and Wet Lowland zones, respectively. Milk production from the dairy cattle sector in Sri Lanka emits about 2.3 million tons $\mathrm{CO}_{2} \mathrm{eq}$
(Fig.3). The emission's profile of milk is dominated by methane ( 93.2 percent), while nitrous oxide $\left(\mathrm{N}_{2} \mathrm{O}\right)$ and carbon dioxide $\left(\mathrm{CO}_{2}\right)$ contribute 1.6 percent and 5.2 percent of the total emissions, respectively. Three sources of emission contribute to the bulk of emissions from dairy cattle. Approximately 88 percent of the emissions arise from methane produced by the rumination of cows and 5 percent from the management of stored manure. $\mathrm{CO}_{2}$ emissions associated with feed production,

Table 4: Summary of selected interventions to mitigate GHG emission in livestock systems in Sri Lanka. Source: FAO \& NZAGGRC 2017.

\begin{tabular}{ll}
\hline Intervention & Objective and constraint addressed \\
\hline Supplementation & •Minimize quantitative and qualitative \\
with fodder trees & deficiency of basal diet to address feed \\
and low-cost con- & seasonality and quality constraints
\end{tabular}
centrate

Mitigation mechanism
umes is attributed to lower fiber
content and faster rate of passage
of feed through the rumen and
therefore intakes are higher with
regular forages

Supplementation $\bullet$ Supplementation of diet with good
with rice straw quality concentrates helps overcome concentrate mix- problem of palatability and digestibility ture

Use of total mixed -Increase efficiency of dietary nutrient ration use by providing critical nutrients that are deficient in the diet and therefore balancing nutrient availability with animal requirements
-A high proportion of concentrate in diet reduces rumen $\mathrm{pH}$ and consequently affects the protozoa population

-Alters human fermentation towards more production of microbial protein and lower volatile fatty acid production improves efficiency of nutrient utilization, improves productivity and reduces methane emission

\begin{tabular}{ll}
\hline $\begin{array}{l}\text { Supplementation } \\
\text { of forage diet with }\end{array}$ & $\begin{array}{l}\text { Improve the quality of low basal diets } \\
\text { and addresses feed availability during }\end{array}$ \\
Gliricidia blocks & periods of scarcity
\end{tabular}

Supplementation Gliricidia blocks
-Provides rumen fermentable nitrogen and by-pass protein to fibrous diets.

-Promotes high dry matter intake and have a faster rate of passage through the rumen and reduction of $\mathrm{CH}_{4} / \mathrm{FPCM}$

\begin{tabular}{|c|c|c|}
\hline $\begin{array}{l}\text { Under health man- } \\
\text { agement } \\
\text { (prevention of } \\
\text { mastitis) }\end{array}$ & $\begin{array}{l}\text {-Improve health status of animals, in- } \\
\text { crease productivity } \\
\text { - Reduce economic losses for farmers } \\
\text { and reduce human health risks, High } \\
\text { morbidity } \\
\text { - Reduced milk production and milk } \\
\text { wastage }\end{array}$ & $\begin{array}{l}\text {-Enhanced animal productivity } \\
\text { and reduced GHG emission in- } \\
\text { tensity. }\end{array}$ \\
\hline $\begin{array}{l}\text { Animal comfort } \\
\text { (heat stress man- } \\
\text { agement) }\end{array}$ & $\begin{array}{l}\text {-Improve productive and reproductive } \\
\text { performance of animals } \\
\text {-Addresses reduced milk production, } \\
\text { decreased reproductive efficiency }\end{array}$ & $\begin{array}{l}\text {-Enhanced animal productivity } \\
\text { and reduced GHG emission in- } \\
\text { tensity. }\end{array}$ \\
\hline
\end{tabular}


transport and processing contribute an additional 5 percent to total emissions. At the national level, the emission intensity of milk produced in Sri Lanka is on average $6.9 \mathrm{~kg}$ $\mathrm{CO}_{2}$ eq. $/ \mathrm{kg} \mathrm{FPCM}$; the highest values were estimated for the low input-output dairy systems in the Dry Lowland zone and the lowest in in the intensive systems in the Upland and Mid-country production zone. Emissions were on average, $13.8,6.8,4.8$ and $2.3 \mathrm{~kg}$ $\mathrm{CO}_{2}$ eq. $/ \mathrm{kg}$ FPCM (fat and protein corrected milk) for the Dry Lowland, Coconut Triangle, Wet Lowland and Upland and Mid-Country systems, respectively. A summary of selected interventions to mitigate GHG emission in livestock systems in Sri Lanka are shown in Table 3.

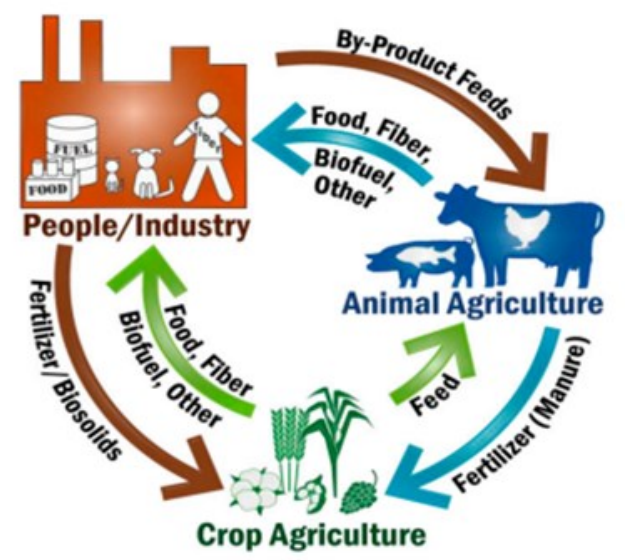

Figure 4: United States food production as an ecosystem with transactions between components (White and Hall (2017).

\section{Nutritional and GHG impacts of removing animals from agriculture}

White and Hall (2017), suggests that removing animals from US agriculture would reduce agricultural GHG emissions, but would also create a food supply incapable of supporting the US population's nutritional requirements (Fig. 4). US agriculture was modelled to determine the impacts of removing farmed animals on food supply adequacy and GHG emissions. The modelled system without animals increased total food production $(23 \%)$, altered foods available for domestic consumption, and decreased agricultural US GHGs (28\%), but only reduced total US GHG by 2.6 percentage units.
Compared with systems with animals, diets formulated for the US population in the plants -only systems had greater excess of dietary energy and resulted in a greater number of deficiencies in essential nutrients. The results give insights into why decisions on modifications to agricultural systems must be made based on a description of direct and indirect effects of change and a dietary, rather than an individual nutrient, basis.

Valin et al. (2013) investigated the effects of crop yield and livestock feed efficiency scenarios on GHG emissions from agriculture and land-use change in developing countries. The results confirmed that yield increase could mitigate some agriculture-related emissions growth over the next decades. Closing yield gaps by $50 \%$ for crops and $25 \%$ for livestock by 2050 would decrease agriculture and land-use change emissions by $8 \%$ overall, and by $12 \%$ per calorie produced. However, the outcome is sensitive to the technological path and which factor benefits from productivity gains: sustainable land intensification would increase GHG savings by one-third when compared with a fertilizer intensive pathway. Reaching higher yield through total factor productivity gains would be more efficient on the food supply side but halve emissions savings due to a strong rebound effect on the demand side. Improvement in the crop or livestock sector would have different implications: crop yield increase would bring the largest food provision benefits, whereas livestock productivity gains would allow the greatest reductions in GHG emission. Combining productivity increases in the two sectors appears to be the most efficient way to exploit mitigation and food security cobenefits.

\section{ACKNOWLEDGEMENT}

The author gratefully acknowledged the fruitful discussions and the support given by Dr. MCN Jayasuriya in the preparation of this manuscript.

\section{REFERENCES}

Arriola KG, Kim SC, Staples CR and Adesogan AT 2011 Effect of fibrolytic enzyme application to low- and high- 
concentrate diets on the performance of lactating dairy cattle. Journal of Dairy Science, 94: 832-841.

Baker SK 1999 Rumen methanogens, and inhibition of methanogenesis. Australian Journal of Agricultural Research, 50: 1293-1298.

Bannink A, France Lopez S, Gerrits WJJ, Kebreab E, Tamminga S and Dijkstra J 2008 Modelling the implications of feeding strategy on rumen fermentation and functioning of the rumen wall. Animal Feed Science Technology, 143: 3-26, <doi:10.1016/ j.anifeedsci.2007.05.002>.

Bannink A, Kogu J, Dijkstra J, France J, Tamminga S and Van Vuuren AM 2000 Modelling production and portal appearance of volatile fatty acids in cows. In: McNamara JP, France J and Beever DE (eds.), Modelling Nutrient Utilisation in Farm Animals. CAB International, Wallingford, UK, 87$102 \mathrm{pp}$.

Beauchemin KA, McGinn SM, Benchaar C and Holtshausen L 2009 Crushed sunflower, flax, or canola seeds in lactating dairy cow diets: Effects on methane production, rumen fermentation, and milk production. Journal of Dairy Science, 92: 2118-2127.

Bustamante Mercedes MC, Carlos A Nobre, Roberto Smeraldi, Ana PD Aguiar, Luis G Barioni, Laerte G Ferreira, Karla Longo, Peter May, Alexandre S Pinto and Jean PHB Ometto 2012 Estimating greenhouse gas emissions from cattle raising in Brazil. Climatic Change, 115:559-577.

Carulla JE, Kreuzer M, Machmuller A and Hess HD 2005 Supplementation of Acacia mearnsii tannins decreases methanogenesis and urinary nitrogen in forage-fed sheep. Australian Journal of Agricultural Research, 56: 961970.

Clough JL Ray, Bucktought LE, Calder J, Baird D, O'Callaghan M, Sherlock RR and Condron LM 2009 The mitigation potential of hippuric acid on $\mathrm{N} 2 \mathrm{O}$ emissions from urine patches: an in situ determination of its effect Soil
Biology and Biochemistry, 41:22222229.

Coleman GS 1986 The metabolism of rumen ciliate protozoa. FEMS Microbiology Reviews, 39:321-344.

Demeyer DI 1991 Quantitative aspects of microbial metabolism in the rumen and hindgut. In: Rumen Microbial Metabolism and Ruminant Digestion. Jouany JP (ed). Institut National de la Recerche Agronomique, 75338 Paris Cedex 07, 217-237pp

Dong Y, Bae HD, McAllister TA, Mathison GW, Cheng KJ 1997 Lipid-induced depression of methane production and digestibility in the artificial rumen system (RUSITEC). Canadian Journal of Animal Science, 77:269-278. doi:10.4141/A96-078.

Dunkley CS and Dunkley KD 2013 REVIEW Greenhouse Gas Emissions from Livestock and Poultry Agriculture, Food and Analytical Bacteriology, 3(1):17-29.

Eugène $\mathrm{M}$, Masse $\mathrm{D}$, Chiquette $\mathrm{J}$ and Benchaar C 2004 Meta-analysis on the effects of lipid supplementation on methane production in lacting dairy cows. Canadian Journal of Animal Science, 88:331-334.

Food and Agriculture Organization of the United Nations and the New Zealand Agricultural Greenhouse Gas Research Centre 2017. Options for lowemission development in the SRI LANKA dairy sector Reducing enteric methane for food security and livelihoods Rome, 2017.

Gemeda BS and Hassen A 2015 Effect of tannin and species variation on in vitro digestibility, gas, and methane production of tropical browse plants. AsianAustralasian Jouranl of Animal Science 28:188-199.

Giampiero Grossi, Pietro Goglio, Andrea Vitali and Adrian G Williams 2019 Livestock and climate change: impact of livestock on climate and mitigation strategies. Animal Frontiers, 9(1): 6976, $\quad<$ https://doi.org/10.1093/af/ vfy034>. 
Giraldo LA, Tejido ML, Ranilla MJ, Ramos S and Carro MD 2008 Influence of direct-fed fibrolytic enzymes on diet digestibility and ruminal activity in sheep fed a grass hay-based diet. Journal of Animal Science, 86: 16171623.

Grainger C and Beauchemin KA 2011 Can enteric methane emissions from ruminants be lowered without lowering their production? Animal Feed Science and Technology, 166-167: 308320.

Havlík P, Hugo Valin, Mario Herrero, Michael Obersteiner, Erwin Schmid, Mariana C. Rufino, Aline Mosnier, Philip K. Thornton, Hannes Böttcher, Richard T. Conant, Stefan Frank, Steffen Fritz, Sabine Fuss,Florian Kraxner and An Notenbaert 2014 Climate change mitigation through livestock system transitions. PNAS, 111 (10):3709-3714.

Hegarty RS 1999 Reducing rumen methane emissions through elimination of rumen protozoa. Australian Journal of Agricultural Research, 50: 1321-1327.

Henderson G, Cox F, Ganesh S, Jonker A and Young W, Global Rumen Census Collaborators and Peter H Janssen 2015 Rumen microbial community composition varies with diet and host, but a core microbiome is found across a wide geographical range. Scientific Reports, 5:14567, DOI: 10.1038/ srep 14567.

Herrero M, Gerber P, Vellinga T, Garnett T, Leip A, Opio C, Westhoek HJ, Thornton PK, Olesen J, Hutchings N, Montgomery H, Soussana JF, Steinfeld $\mathrm{H}$ and McAllister TA 2016 Livestock and greenhouse gas emissions: The importance of getting the numbers right. Animal Feed Science and Technology, 166-167:779-782.

Herrero M, Benjamin Henderson, Petr Havlík, Philip K Thornton, Richard T Conant, Pete Smith, Stefan Wirsenius, Alexander N Hristov, Pierre Gerber, Margaret Gill, Klaus Butterbach-Bahl, Hugo Valin, Tara Garnett and Elke Stehfest 2016 Greenhouse gas mitiga- tion potentials in the livestock sector. Nature Climate Change, 6: 452-461.

Hironaka R, Mathison GW, Kerrigan BK and Vlach I 1996 The effect of pelleting of alfalfa hay on methane production and digestibility by steers. Science of the Total Environment, 180: 221-227.

Huhtanen P and Nousiainen J 2012 Production responses of lactating dairy cows fed silage based diets to changes in nutrient supply. Livestock Science, 148:146-158.

Hristov AN, Oh J, Lee C, Meinen R, Montes F, Ott T, Firkins J, Rotz A, Dell C, Adesogan A, Yang W, Tricarico J, Kebreab E, Waghorn G, Dijkstra J and Oosting S 2013 Mitigation of greenhouse gas emissions in livestock production-A review of technical options for non- $\mathrm{CO}_{2}$ emissions. In: Gerber PJ, Henderson B and Makkar HPS (eds). FAO Animal Production and Health Paper No. 177. FAO, Rome, Italy.

Immig I 1996 The rumen and hindgut as source of ruminant methanogenesis. Environ Monit Assess, 42(1-2):57-72, $<$ https.//doi: 10.1007/BF00394042>.

IPCC 2007 Climate Change 2007: Synthesis Report. Contribution of Working Groups I, II and III to the Fourth Assessment Report of the Intergovernmental Panel on Climate Change. eds. Pachauri RK and Reisinger A. IPCC, Geneva, Switzerland.

IPCC 2006 IPCC Guidelines for National Greenhouse Gas Inventories. Intergovernmental Panel on Climate Change. NGGIP Publications, IGES, Japan.

Jayanegara A, Makkar HPS and Becker K 2009 Methane reducing properties of polyphenol containing plants simple phenols and purified tannins in in-vitro gas production method, FAO-IAEA International Symposium 'Sustainable Improvement of Animal Production and Health', 8 to 11 June 2009, Vienna, Austria.

Johnson KA and Johnson DE 1995 Methane emissions from cattle. Journal of Animal Science, 73:2483-2492.

Johnson KA, Kincaid RL, Westberg HH, Gaskins CT, Lamb BK and Cronrath JD 
2002 The effect of oilseeds in diets of lactating cows on milk production and methane emissions Journal of Dairy Science, 85: 1509-1515.

Kebreab E, Mills JAN, Crompton LA, Bannink A, Dijkstra J, Gerrits WJJ and France J 2004 An integrated mathematical model to evaluate nutrient partition in dairy cattle between animal and environment. Animal Feed Science Technology, 112:131-154.

Klieve AV and Hegarty RS 1999 Opportunities for biological control of ruminal methanogenesis. Australian Journal of Agricultural Research, 50:1315-1319.

Knapp JR, Laur GL, Vadas PA, Weiss WP and Tricarico JM 2014 Invited review: Enteric methane in dairy cattle production: Quantifying the opportunities and impact of reducing emissions Journal of Dairy Science., 97(6):32313261, < https://doi.org/10.3168/ jds.2013-7234>.

Lesschen JP, Van den Berg M, Westhoek HJ, Witzke HP and O Oenema 2011 Greenhouse gas emission profiles of European livestock sectors. Animal Feed Science and Technology, 166167:16-28.

Mané C, Sommerer N, Yalcin T, Cheynier V, Cole RB and Fulcrand H 2007 Assessment of the Molecular

Weight Distribution of Tannin Fractions through MALDITOF MS Analysis of Protein-Tannin

Complexes. Analytical Chemistry, 79: 2239-2248.

McAllister TA and Newbold CJ 2008 Redirecting rumen fermentation to reduce methanogenesis. Australian Journal of Experimental Agriculture, 48:7-13.

McAllister TA, Okine EK, Mathison GW and Cheng KJ 1996 Dietary, environmental and microbiological aspects of methane production in ruminants. $\mathrm{Ca}-$ nadian Journal of Animal Science, 76: 231-243.

McGinn SM, Beauchemin KA, Iwaasa AD and McAllister TA 2006 Assessment of the Sulfur Hexafluoride (SF6) Tracer Technique for Measuring Enteric Methane Emissions from Cattle.
Journal of Environmental Quality, 35:1686-1691.

Mills JA, Dijkstra J, Bannink A, Cammell SB, Kebreab E and France J 2001 A mechanistic model of whole-tract digestion and methanogenesis in the lactating dairy cow: Model development, evaluation, and application. Journal of Animal Science, 79:1584- 1597.

Mohamad Ramin 2013 Predicting Methane Production in Dairy Cows See discussions, stats, and author profiles for this publication at: https:// www.researchgate.net/ publication/321171254.

Moss AR, Jouany JP and Newbold J 2000 Methane production by ruminants: its contribution to global warming. Annals of Zootechnology, 49: 231-253.

Narvaez N Wang Y and McAllister T 2011 Effects of hops on in vitro ruminal fermentation of diets varying in forage content. Livestock Science, 138:193201

Naumann HD, Armstrong SA, Lambert BD, Muir JP, Tedeschi LO and Kothmann MM 2014 Effect of molecular weight and concentration of legume condensed tannins on in vitro larval migration inhibition of Haemonchus contortus. Veterinary Parasitology, 199: 93-8.

Newbold CJ, Wallace RJ, Chen XB and McIntosh FM 1995 Different strains of Saccharomyces cerevisiae differ in their effects on ruminal bacterial numbers in vitro and in sheep. Journal of Animal Science, 73 (6): $1811-8$

O'Mara FP 2011 The significance of livestock as a contributor to global greenhouse gas emissions today and in the near future. Animal Feed Science and Technology, 166-167:7-15

Ramin M, Alimon AR and Ivan M 2010 Effects of fungal treatment on the in vitro digestion of palm kernal cake. Livestock Research for Rural Development, 22(4): 82.

Slade EM, Riutta T, Roslin T and Tuomisto HL 2016 The role of dung beetles in reducing greenhouse gas emissions 
from cattle farming. Scientific Reports, $6: 18140$

Seresinhe T, Sujani S and Pathirana I 2017 Cellulase Enzyme Enhanced the Diet Digestibility and Growth Performance of Ewes Asian Journal of Animal Sciences 11(4):171-176 DOI:10.3923/ ajas.2017.171.176

Seresinhe T and Iben C 2003 In vitro quality assessment of two tropical shrub legumes in relation to their extractable tannins contents. Journal of Animal Physiology and Animal Nutrition, 87 (2-4):109-115

Shibata M and Terada F 2010 Factors affecting methane production and mitigation in ruminants. Animal Science Journal, 81: 2-10.

Smith P, Daniel M, Zucong C, Daniel G, Janzen H, Kumar P, McCarl B, Olge S, O'mara F, Rice C, Scholes B, Sirotenko O, Howden M, McAllister T, Pan G, Romanekov V, Schneider U, Towprayoon S, Wattenbach $\mathrm{M}$ and Smith J 2008 Greenhouse gas mitigation in agriculture. Philosophical Transactions of the Royal Society B, 363:789-813.

Soltan Y, Abdella AL, Silva LRF and Natel AS 2013 Fibrolytic enzymes for tropical pastures Response of Different Tropical Pasture Grass Species to Treatments with Fibrolytic Enzymes in Terms of In Vitro Ruminal Nutrient Degradation and Methanogenesis. Animal Nutrition and Feed Technology, 13(8): 551.

Soares S, Mateus N and Freitas V De 2007 Interaction of different polyphenols with bovine serum albumin (BSA) and human salivary alpha-amylase (HSA) by fluorescence quenching. Journal of Agricultural and Food Chemistry, 55:6726-6735.

Sujani S, Perera ANF and Seresinhe RT 2017 Tannin binding agents enhanced in vitro rumen fermentation parameters of two tanniniferous tree fodder species. International Journal of Agricultural Sciences and Veterinary Medicine, 5(2): May 2017, < http:// www.ijasvm.com/currentissue.php >
Sujani S and RT Seresinhe 2015 Exogenous Enzymes in Ruminant Nutrition: A Review Asian Journal of Animal Sciences, 9 (3): 85-99.

Sveinbjörnsson $\mathrm{J}$, Huhtanen $\mathrm{P}$ and Udén $\mathrm{P}$ 2006 The Nordic dairy cow model, Karoline - development of volatile fatty acid sub-model. In: Kebreab E, Dijkstra J, Bannink A, Gerrits WJJ and France J (eds). Nutrient Digestion and Utilization in Farm Animals: Modeling Approaches. CABI Oxfordshire, UK, 1-14pp.

Tavendale MH, Meagher LP, Pacheco D, Walker N, Graeme TA and Sivakumaran S 2005 Methane production from in vitro rumen incubations with Lotus pedunculatus and Medicago sativa, and effects of extractable condensed tannin fractions on methanogenesis. Animal Feed Science and Technology 123 (part 1):403-419.

Togtokhbayar Norovsambuu, María A Cerrillo, Germán Buendía Rodríguez, Mona MMY Elghandour, Abdelfattah ZM Salem, Chuluunbaatar Urankhaich, Sukhbaatar Jigjidpurev, Nicholas E Odongo, Ahmed E Kholif 2015 Effect of exogenous xylanase on rumen in vitro gas production and degradability of wheat straw. Animal Science Journal, 86(8):765-771.

Thornton PK and Herrero M 2010 The potential for reduced methane and carbon dioxide emissions from livestock and pasture management in the tropics. Proceedings of the National Academy of Sciences of theUSA 107:1966719672.

Vogels G, Hoppe W and Stumm C 1980 Association of methanogenic bacteria with rumen ciliates. Applied and Environmental Microbiology, 40: 608-612.

Valin H, Havl'ik P, Mosnier A, Herrero M, Schmid E and Obersteiner M 2013 Agricultural productivity and greenhouse gas emissions: trade-offs or synergies between mitigation and food security? Environmental Research Letters, 8:035019 9pp.

Waghorn GC, Tavendale $\mathrm{MH}$ and Woodfield DR 2002 Methanogenesis from 
forages fed to sheep. Proceedings of the New Zealand Grassland Association, 64:159-165.

Weiss Franz and Adrian Leip 2011 Greenhouse gas emissions from the EU livestock sector: A life cycle assessment carried out with the CAPRI model Agriculture. Ecosystems and Environment, 149: 124-134.

White Robin R and Mary Beth Hall 2017 Nutritional and greenhouse gas impacts of removing animals

from US agriculture, Proceedings of the National Academy of Sciences of the USA, 114: E10301-E10308pp, https://doi.org/10.1073/

pnas. 170732211429133422

Wirsenius Stefan, Fredrik Hedenus and Kristina Mohlin 2011 Greenhouse gas taxes on animal food products: rationale, tax scheme and climate mitigation effects. Climatic Change, 108:159-184, $<$ https://doi. org/10.1007/s10584-0109971-x>.

Wolin MJ and Miller TL 1988 Microbe interactions in the rumen microbial ecosystem. In: The Rumen Ecosystem. Hobson PN (Ed.). Elsevier Applied Science, New York.

Wolin MJ and Miller TL 2006 Control of rumen methanogenesis by inhibiting the growth and activity of methanogens with hydroxymethylglutaryl-SCoA inhibitors. International Congress Series, 1293: 131-137.

Wright ADG, Kennedy P, O’Neill CJ, Toovey AF, Popovski S, Rea SM, Pimma CL and Klein L 2004 Reducing methane emissions in sheep by immunization against rumen methanogens. Vaccine, 22:3976-3985. 